\title{
Vitamin D deficiency treated by consuming UVB-irradiated mushrooms
}

\author{
Andrew Ozzard, Gurdip Hear, Gavin Morrison and Mike Hoskin
}

\begin{abstract}
Deficiency of vitamin $D$ is usually caused by dietary deficiency and/or lack of exposure to sunlight in dark skinned individuals living at northern latitudes. Simple vitamin $\mathrm{D}$ deficiency is commonly treated by prescribing a vitamin $\mathrm{D}$ containing calcium supplement. This report presents a patient who rejected this approach and instead, after researching alternative treatment options independently, opted to self-treat by consuming UVB-irradiated mushrooms. The beneficial effect of this on the patient's plasma biochemical markers is shown. Further research into the beneficial effect of consuming UVB-irradiated mushrooms is required.
\end{abstract}

Keywords

food irradiation; vitamin $D$; vitamin $D$ deficiency.
A Ozzard, DCH, MRCPCH, GP registrar; G Hear, BSc, DCH, DRCOG, DFFP, MRCGP, GP trainer; M Hoskin, DRCOG, MRCGP, GP trainer, Crosby House Surgery, Slough; G Morrison, MBBS, FY1, Leighton Hospital, Crewe, Cheshire.

Address for correspondence

Dr Andrew Ozzard, Crosby House Surgery, 91 Stoke Poges Lane, Slough, SL1 3NY. E-mail: andy_ozzard@yahoo.co.uk

Submitted: 21 February 2008; Editor's response: 15 April 2008; final acceptance: 6 May 2008.

(OBritish Journal of General Practice 2008; 58: 644-645.

DOI: 10.3399/bjgp08X341959

\section{INTRODUCTION}

Vitamin $\mathrm{D}$ is a fat-soluble vitamin whose main role in the body is in calcium homeostasis, namely stimulating osteoclastic resorption of bone and increasing calcium and phosphate reabsorption in the gut. In addition, more recent evidence suggests that an adequate serum vitamin $\mathrm{D}$ level may play a preventive role in the development of autoimmune diseases - such as insulin-dependent diabetes mellitus $^{1}$ and multiple sclerosis, ${ }^{2}$ as well as certain cancers $^{3-5}$ - and also result in improved survival in patients with early lung cancer. ${ }^{6}$

Deficiency of vitamin $D$ is particularly high among dark-skinned individuals living at northern latitudes. One study has assessed the prevalence as being around $14.5 \%$ in the UK's adult population, but up to $94 \%$ in South Asian adults living in the UK. ${ }^{7}$ Further studies have shown that other non-white ethnic groups within the UK have increased prevalence. $^{8}$

The active form of Vitamin $D$ is known as vitamin D3, or 1,25-dihydroxycholecalciferol. This is derived either from diet or ultraviolet B (UVB) light conversion of 7-dehydrocholesterol in the skin, which is then hydroxylated to 25-hydroxyvitamin D in the liver, and then further hydroxylated to 1,25 -dihydroxycholecalciferol in the kidneys. The measurement of serum 25-hydroxyvitamin D levels is widely accepted to be an accurate reflection of serum 1,25-dihydroxyvitamin $D$ levels.

The main dietary source of vitamin $D$ has long been thought to be cod liver oil and oily fish. Edible mushrooms have been shown to be abundant in ergocalciferol, which can then be hydroxylated to 25-hydroxyvitamin $D$ in the liver. This can be further hydroxylated to the active form, 1,25dihydroxyvitamin $\mathrm{D}$, in the kidneys.

It is known that ingestion of edible mushrooms can result in an increase in serum vitamin $D$ levels in humans, ${ }^{9}$ and it is also known that irradiating mushrooms with UVB light leads to an increase in their vitamin $D$ content. ${ }^{10}$ Furthermore, in vivo studies in rats have shown an increase in both serum 25-hydroxyvitamin D levels and bone mineral density following ingestion of UVB-irradiated mushrooms. ${ }^{11}$ To date, no human studies have been published showing a similar effect. 
Table 1. Biochemical values.

\begin{tabular}{lcc} 
Serum level & $\begin{array}{c}\text { Initial } \\
\text { result }\end{array}$ & $\begin{array}{c}\text { After } \\
3 \text { months' } \\
\text { treatment }\end{array}$ \\
\hline $\begin{array}{l}\text { 25-hydroxyvitamin D, nmol/l } \\
\text { (normal range: } 25-120 \mathrm{nmol} / \mathrm{l})\end{array}$ & 17 & 39 \\
\hline $\begin{array}{l}\text { Parathyroid hormone, } \mathrm{pmol} / \mathrm{l} \\
\text { (normal range: } 1.60-6.90 \mathrm{pmol} / \mathrm{l})\end{array}$ & 9.30 & 5.60 \\
\hline $\begin{array}{l}\text { Corrected calcium, } \mathrm{mmol} / \mathrm{l} \\
\text { (normal range: } 2.15-2.55 \mathrm{mmol} / \mathrm{l} \text { ) }\end{array}$ & 2.16 & 2.25 \\
\hline
\end{tabular}

\section{CASE HISTORY}

This report presents a 30-year old Indian male living in Slough in south-east England. He eats a purely vegetarian diet for religious reasons but does consume dairy products. In the past, he had been told he was deficient in vitamin $\mathrm{D}$ but had not been treated. Repeat testing showed he was, indeed, deficient in vitamin D, with an appropriate secondary rise in serum parathyroid hormone levels (Table 1).

Calcichew $^{\circledast} D_{3} \quad$ (Shire, Basingstoke) was prescribed; however, after doing his own research this patient decided to self-treat. He bought a UVB bulb from a local hardware shop and proceeded to shine this directly onto approximately $200 \mathrm{~g}$ of button mushrooms daily, from a distance of approximately $15 \mathrm{~cm}$, before stir-frying and consuming them. He repeated this on a daily basis for 3 months.

During the 3 months prior to repeat blood testing, which coincided with the English winter, the patient made no other lifestyle changes. Specifically, his diet remained identical in every other way to before, and he did not leave the UK. However, repeat blood testing showed an increase in serum 25 -hydroxyvitamin D level of $129 \%$, with a concomitant appropriate decrease in the serum parathyroid hormone level.

Given the apparent rise in this patient's serum 25-hydroxyvitamin D levels after following this regime strictly for just 3 months, it would appear reasonable to hypothesise that UVB-irradiated mushrooms may be able to provide a source of vitamin $\mathrm{D}$ for those whose diet, lifestyle, and/or skin colour results in them being at risk of deficiency.

Further studies including randomised controlled trials are required in order to test this hypothesis.

\section{Consent}

The patient has consented to the publication of this report Competing interests

The authors have stated that there are none.

Discuss this article

Contribute and read comments about this article on the

Discussion Forum: http://www.rcgp.org.uk/bjgp-discuss

\section{REFERENCES}

1. Chiu K, Chu A, Go V, Saad M. Hypovitaminosis D is associated with insulin resistance and beta cell dysfunction. Am J Clin Nutr 2004; 79(5): 820-825.

2. Munger K, Levin L, Hollis B, et al. Serum 25-hydroxyvitamin D levels and risk of multiple sclerosis. JAMA 2006; 296(23): 2832-2838.

3. Wu K, Feskanich D, Fuchs C, et al. A nested case control study of plasma 25-hydroxyvitamin D concentrations and risk of colorectal cancer. J Natl Cancer Inst 2007; 99(14): 1120-1129.

4. Park SY, Murphy S, Wilkens L, et al. Calcium and vitamin D intake and risk of colorectal cancer: the Multiethnic Cohort Study. Am J Epidemiol 2007; 165(7): 784-793.

5. Lin J, Manson J, Lee I, et al. Intakes of calcium and vitamin D and breast cancer risk in women. Arch Intern Med 2007; 167(10): 1050-1059.

6. Zhou W, Heist R, Liu G, et al. Circulating 25-hydroxyvitamin D levels predict survival in early-stage non-small-cell lung cancer patients. J Clin Oncol 2007; 25(5): 479-485.

7. Primary vitamin D deficiency in children. Drug Ther Bull 2006; 44(2): 12-16.

8. Mytton J, Frater AP, Oakley G, et al. Vitamin D deficiency in multicultural primary care. Br J Gen Pract 2007; 57(540): 577-579.

9. Outila T, Mattila P, Piirornen V, Lamberg-Allardt C. Bioavailability of vitamin D from wild edible mushrooms as measured with a human bioassay. Am J Clin Nutr 1999; 69(1): 95-98.

10. Jasinghe VJ, Perera CO. Distribution of ergosterol in different tissues of mushrooms and its effect on the conversion of ergosterol vitamin $\mathrm{D}_{2}$ by UV irradiation. Food Chemistry 2005; 2: 541-546.

11. Jasinghe VJ, Perera CO, Barlow PJ. Bioavailability of vitamin $\mathrm{D}_{2}$ from irradiated mushrooms: an in vivo study. Br J Nutr 2005; 93(6): 951-955. 